\title{
SYNTHESIS, MOLLUSCICIDALAND ANTIMICROBIAL POTENTIALITIES OF IRON TRIAD MONONUCLEAR METAL COMPLEXES INCORPORATING TRIDENTATE ASYMMETRICAL SCHIFF BASE LIGANDS CONTAINING SOFT SULFUR COORDINATING ATOM
}

\author{
AMAL M ALOSAIMI, INES EL MANNOUBI, SAMI A ZABIN* \\ Department of Chemistry, Faculty of Science, Al Baha University, Al Baha, KSA. Email: samizabin@gmail.com \\ Received: 25 November 2019, Revised and Accepted: 19 December 2019
}

ABSTRACT

Objective: This work aimed at synthesizing tridentates asymmetrical Schiff base ligands containing sulfur atom and using them for preparing metal complexes with the iron triad metals. The prepared compounds were assayed in vitro for antimicrobial potential and in vivo molluscicidal activity.

Methods: The unsymmetrical tridentate Schiff bases $\left(\mathrm{SL}_{1}, \mathrm{SL}_{2}\right.$, and $\left.\mathrm{SL}_{3}\right)$ were prepared using 2-aminothiophenol as primary amine and condensed with 2-carboxybenzaldehyde, 2-hydroxy-1-naphthaldehyde, and 7-formyl-8-hydroxyquinoline. These ligands were used in preparing metal complexes with iron triad metals. The synthesized Schiff base ligands and their corresponding metal complexes were characterized and their proposed structures were confirmed using different physical and spectroscopic analytical techniques. All ligands and their corresponding metal complexes were assayed against different bacterial and fungal strains using the agar disk-diffusion technique. The molluscicidal activity was performed according to the standard reported methods as cited in the literature and by observing the toxicity and lethal dose according to the WHO guidelines.

Results: The synthesized ligands behave as tridentate (NOS) ligands and form mononuclear complexes with the general formula [M(SL) ${ }_{2}$ with an octahedral geometry around the central metal ion. Metal complexes were non-electrolytic in nature. The in vitro antibacterial and antifungal examination results showed weak activity of the ligands, and there was enhanced activity with the complexes. The in vivo molluscicidal activity of the tested compounds showed good activity.

Conclusion: The targeted compounds were prepared successfully, characterized, and showed some biological activity but lower than the standard reference drugs.

Keywords: Asymmetrical Schiff base ligands, Iron triad metals, Metal complexes, Molluscicidal, Antibacterial, Antifungal.

(C) 2020 The Authors. Published by Innovare Academic Sciences Pvt Ltd. This is an open access article under the CC BY license (http://creativecommons. org/licenses/by/4. 0/) DOI: http://dx.doi.org/10.22159/ajpcr.2020.v13i2.36481

\section{INTRODUCTION}

Metal complexes involving Schiff base ligands constitute a leading active and fertilize research area [1-3]. The literature is very rich in the published work on Schiff base complexes, and many studies reported wide-ranging applications of Schiff base metal complexes in many scientific areas particularly, the pharmaceutical and medicinal field [4-7]. The biological significance of the Schiff base complexes is of no doubt due to the presence of the azomethine group and the ability to design metal complexes containing model systems that able to mimic biological systems [8-10].

Investigating symmetrical and asymmetrical systems of Schiff base ligands for chelation with metal ions and assessing their biological application represent an important research issue in coordination chemistry [3,11-14]. The interest in designing and preparation of symmetrical and unsymmetrical Schiff bases derived from the ease of preparation using different molar ratio condensation reactions between different carbonyl and amine compounds. The interest in studying this type of compound is generated from their prospective applications in biologically active drugs and as models in bioinorganic chemistry $[12,15,16]$. Moreover, the attention for preparing metal complexes with unsymmetrical Schiff base ligands is because most of the coordinated ligands in natural systems around the central metal atom are unsymmetrical [11]. Unsymmetrical Schiff base ligands have an advantage over their symmetrical counterparts in the elucidation of compounds structure and prediction of geometry in the bioinorganic system $[10,17]$.
The unsymmetrical Schiff base ligands containing soft-hard donor atoms (N, O, and $\mathrm{S}$ ) have been reported to increase the chelation ability forming highly stable versatile complexes with different structures and having different applications in bioinorganic, medicinal, optical, and thermal fields [1,18-20].

In view of the facts mentioned above, we are encouraged and considered interesting to design new Schiff base ligand compounds in a trial to develop chemical compounds with different scaffolds in one structure, which may lead to interesting biologically active agents. The suggested ligands were synthesized using the primary amine compound 2-amino thiophenol, which was condensed with 2-carboxybenzaldehyde, 2-hydroxy-1-naphthaldehyde, and 7-formyl8-hydroxyquinoline. The synthesized asymmetrical Schiff bases were used to synthesize metal complexes by reaction with iron triad metal ( $\mathrm{Fe}, \mathrm{Co}$, and $\mathrm{Ni}$ ) salts in proper molar ratio. Moreover, free ligands and their corresponding metal complexes were characterized and examined for their molluscicidal, antibacterial, and antifungal potentials.

\section{METHODS}

Chemicals, analytical, and physical measurements

The starting chemicals usedin thisstudy were of analytical grade purchased from Sigma-Aldrich, Acros Organics, and Luba Chemical Companies and were used in reactions as received without further purification. 7-fromyl8-hydroxyquinoline precursor was synthesized in our laboratory, as given below following well-known literature procedures [21,22]. 
The melting points were measured utilizing the digital melting point apparatus model A9100 electrothermal series.

Elemental analysis was performed using the Thermo Fisher Scientific CHN/S/O analyzer instrument (Leco Model VTF-900 CHN-S-O 932 version 1.3× USA). Mass spectra were recorded on the Thermo Scientific-LCQ fleet ion trap mass spectrometer using electrospray ionization method. For determining the metal percentage in the prepared compounds, we used an inductively coupled plasma (ICP) spectrophotometer (Thermo Scientific ICP-7000 plus Series ICP-OS).

Fourier-transform infrared (FT-IR) spectra were recorded using the Thermo Scientific Nicolet iS50 FT-IR spectrophotometer in the range of $400-4000 \mathrm{~cm}^{-1}$ utilizing attenuated total reflection method for direct measurement of the IR spectrum for the powder solid samples. The ultraviolet (UV)-visible absorption spectra were recorded in dimethyl sulfoxide (DMSO) solutions on an evolution 300 UV-visible double beam spectrophotometer (Thermo Fisher scientific company). ${ }^{1} \mathrm{H}$ nuclear magnetic resonance (NMR) and ${ }^{13} \mathrm{C}$ NMR spectra were recorded on Varian Mercury-400BB ( $400 \mathrm{MHz}$ ) spectrometer. Molar conductivity was measured using AP85 Portable Waterproof $\mathrm{pH} /$ conductivity meter using $1.0 \times 10^{-3} \mathrm{M}$ solutions in DMSO or dimethylformamide (DMF) at room temperature. The magnetic susceptibility measurement of the prepared metal complexes was measured using Gouy's Apparatus (Model No: HO-ED-EM-08) at room temperature. Thermogravimetric analysis (TGA) was performed on Shimadzu Thermogravimetric Analyzer Model DTG-60H in a dynamic nitrogen atmosphere $\left(20 \mathrm{ml} / \mathrm{min}\right.$ ) at a heating rate of $10^{\circ} \mathrm{C} / \mathrm{min}$ in the temperature range of $25-1000^{\circ} \mathrm{C}$.

\section{Synthesis of 7-formyl-8-hydroxyquinoline}

The precursor compound 7-formyl-8-hydroxyquinoline was prepared from 8-hydroxyquinoline following the reported method [21,22]. A mixture of $1.45 \mathrm{~g}(0.1 \mathrm{~mol})$ of 8-hydroxyquinoline, $8.5 \mathrm{~mL}$ of chloroform and $90 \mathrm{~mL}$ of $15 \% \mathrm{NaOH}$ were heated under reflux for $4 \mathrm{~h}$ on a water bath. The reaction mixture was cooled at room temperature and the $\mathrm{pH}$ of the solution was adjusted between 5.5 and 5.8 using $0.1 \mathrm{M} \mathrm{HCl}$ solution. A pale brown product was separated out and left to coagulate. The precipitate was collected by filtration and then recrystallized from $80 \%$ ethanol to get pale brown solid. The yield $(87.35 \%)$ obtained was in good quantity. The melting point measured was $210^{\circ} \mathrm{C}$.

Preparation of Schiff base ligand 2-\{[(2-mercaptophenyl)imino]methyl\} benzoic acid $\left(S L_{1}\right)$

The organic unsymmetrical Schiff base ligands used in this investigation were generally synthesized according to the standard reported methods, as cited in the literature [23,24]. Schiff base ligand $\left(\mathrm{SL}_{1}\right)$ was prepared by mixing $20 \mathrm{~mL}$ solution of 2 -aminothiophenol $(5 \mathrm{mmol}$, $0.63 \mathrm{~g}$ ) and $20 \mathrm{~mL}$ solution of 2-carboxybenzaldehyde $(5 \mathrm{mmol}, 0.76 \mathrm{~g})$ in absolute ethanol. The reaction mixture was refluxed for about 8 h with continuous stirring. After cooling at room temperature, the obtained precipitate was filtered and washed with n-hexane and finally dried in the open air. The yellowish-white solid was recrystallized using hot ethanol to give a pure compound with a yield of $83.54 \%$. The melting point found to be $130^{\circ} \mathrm{C}$. The reaction for the synthesis of $\mathrm{SL}_{1}$ ligand is illustrated in Scheme 1.

Molecular formula $\left(\mathrm{C}_{14} \mathrm{H}_{11} \mathrm{NO}_{2} \mathrm{~S}\right), \quad \mathrm{m} / \mathrm{z}: 256.00 \quad[\mathrm{~L}-\mathrm{H}]^{+} \quad$ (Mol. Wt. $=257 \mathrm{~g} \mathrm{~mol}^{-1}$ ). Elemental analysis: Calculated (found) $\% \mathrm{C}$ 65.36 (65.52); \%H 4.31 (4.15); \%N 5.45 (5.50); \%O 12.44 (12.40); \%S $12.44(12.62)$.

Preparation of Schiff base ligand 1-((E)-(2-mercaptophenylimino) methyl)naphthalen-2-ol $\left(\mathrm{SL}_{2}\right)$

The Schiff base ligand $\left(\mathrm{SL}_{2}\right)$ was prepared by mixing $20 \mathrm{~mL}$ ethanolic solution of 2-aminothiophenol (10 mmol, $1.25 \mathrm{~g})$ and $30 \mathrm{~mL}$ ethanolic solution of 2-hydroxy-1-naphthaldehyde $(10 \mathrm{mmol}, 1.72 \mathrm{~g})$ in roundbottom flask and the reaction mixture was refluxed using a condenser fitted with guard tube with calcium chloride for $1 \mathrm{~h}$. The reaction mixture was cooled after completion of the reaction in an ice bath and kept overnight where on light yellow crystalline precipitate was formed. The product was filtered off, washed with ethanol, and finally dried in the open air. The yield obtained was about $65.50 \%$ and the melting point was measured at $131.3^{\circ} \mathrm{C}$. The reaction for the synthesis of $\mathrm{SL}_{2}$ ligand is illustrated in Scheme 2.

Molecular formula $\left(\mathrm{C}_{17} \mathrm{H}_{13} \mathrm{NOS}\right), \quad \mathrm{m} / \mathrm{z}: 278.08 \quad[\mathrm{~L}-\mathrm{H}]^{+} \quad($ Mol. $\mathrm{Wt} .=279 \mathrm{~g} \mathrm{~mol}^{-1}$ ). Elemental analysis: Calculated (found) \%C 73.10 (72.96); \%H 4.69 (4.43); \%N 5.02 (5.4.9); \%O 5.73 (5.66); \%S $11.46(11.17)$

Preparation of Schiff base ligand 7-((E)-(2-mercaptophenylimino) methyl)quinolin-8-ol (SL $\left.{ }_{3}\right)$

$\mathrm{SL}_{3}$ ligand was prepared by mixing a solution of 2-aminothiophenol ( $5 \mathrm{mmol}, 1.25 \mathrm{~g}$ ) in $20 \mathrm{~mL}$ absolute ethanol with a solution of 7-formyl8-hydroxyquinoline ( $5 \mathrm{mmol}, 1.73 \mathrm{~g}$ ) in $40 \mathrm{~mL}$ chloroform. The whole mixture was refluxed for about $8 \mathrm{~h}$ with continuous stirring using hot stage magnetic stirrer and maintaining the temperature between $65^{\circ} \mathrm{C}$ and $80^{\circ} \mathrm{C}$. After completion of the reaction, the mixture was cooled atroom temperature when a brownish-orange solid precipitate was obtained, which was filtered and dried in the open air at room temperature. The obtained Schiff base product was purified by recrystallization using chloroform and ethanol mixture (50:50). The yield obtained was about $85.23 \%$ and the melting point was measured $260^{\circ} \mathrm{C}$. The reaction for the synthesis of $\mathrm{SL}_{3}$ ligand is illustrated in Scheme 3.

Molecular formula $\left(\mathrm{C}_{16} \mathrm{H}_{12} \mathrm{~N}_{2} \mathrm{OS}\right), \quad \mathrm{m} / \mathrm{z}: 279.08 \quad[\mathrm{~L}-\mathrm{H}]^{+} \quad(\mathrm{Mol}$. Wt. $=280 \mathrm{~g} \mathrm{~mol}^{-1}$ ). Elemental analysis: Calculated (found) \%C 68.55 (68.24); \%H 4.32 (4.15); \%N 10.00 (10.33); \%O 5.71 (5.78); \%S $11.42(11.58)$

\section{General procedure for preparation of metal complexes}

The targeted Fe, Co, and Ni metal complexes were prepared following the general reported method by the reaction between the solution of<smiles>Nc1ccccc1S</smiles>

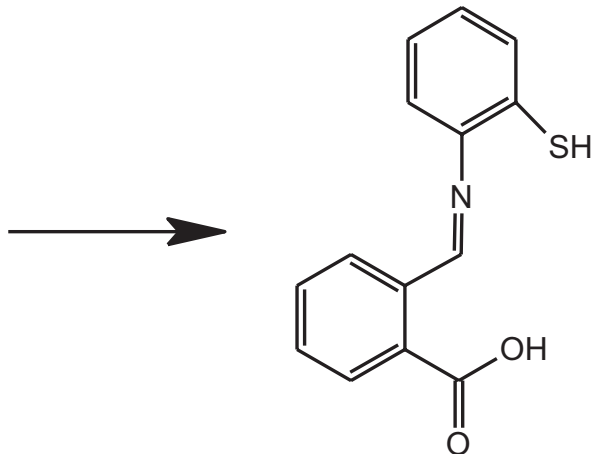

Scheme 1: Synthesis of $\mathrm{SL}_{1}$ 
<smiles>CC(C)CCCCCC=O</smiles>

Scheme 2: Synthesis of $\mathrm{SL}_{2}$<smiles>Cc1cccc(/N=C/c2ccc3cccnc3c2O)c1S</smiles>

Scheme 3: Synthesis of $\mathrm{SL}_{3}$

the hydrated metal salts of $\mathrm{Fe}, \mathrm{Co}$, and Ni with the solution of the Schiff base ligands $[2,18]$. The proper amount of the metals salt was dissolved in the proper solvent and mixed with the solution of the prepared Schiff base ligands (in proper metal to ligand stoichiometric ratio) in the round-bottom flask and refluxed and stirred using hot stage magnetic stirrer for 4-6 $\mathrm{h}$ until the reaction is completed. Then, the isolated crude products were filtered washed sequentially with hot ethanol and finally with ether. The compounds were purified by recrystallization, dried, and weighted. The yield and color observed are shown for each complex below. All metal complexes obtained were colored, air-stable compounds, and insoluble in common organic solvents but soluble in DMSO and hot DMF solvents. The measured melting points for all metal complexes were $>300^{\circ} \mathrm{C}$.

$\left[\mathrm{Fe}\left(\mathrm{SL}_{1}\right)_{2}\right]$ : Dark brown solid; yield $=88.21 \%$; $\mathrm{mp}:>300^{\circ} \mathrm{C}$. Molecular formula $\left(\mathrm{FeC}_{28} \mathrm{H}_{18} \mathrm{~N}_{2} \mathrm{O}_{4} \mathrm{~S}_{2}\right.$ ), m/z: 567.10 (Mol. Wt.: $566.43 \mathrm{~g} / \mathrm{mol}$ ). Elemental analysis: Calculated (found) \%C $59.16 \quad(58.82) ; \% \mathrm{H}$ 3.55 (3.68); \%N 4.93 (5.12); \%0 11.27 (10.86); \%S 11.26 (11.46); \%Fe $9.83(9.65)$.

$\left[\mathrm{Ni}\left(\mathrm{SL}_{1}\right)_{2}\right]$ : Dark green solid; yield $=96.74 \%$; $\mathrm{mp}:>300^{\circ} \mathrm{C}$. Molecular formula $\left(\mathrm{NiC}_{28} \mathrm{H}_{18} \mathrm{~N}_{2} \mathrm{O}_{4} \mathrm{~S}_{2}\right.$ ), m/z: 569.67 (Mol. Wt.: $569.28 \mathrm{~g} / \mathrm{mol}$. Elemental analysis: Calculated (found) \%C 58.87 (58.60); \%H 3.53 (3.74); \%N 4.91 (4.90); \%0 11.22 (10.96); \%S 11.20 (11.46); \%Ni $10.28(10.72)$

$\left[\mathrm{Co}\left(\mathrm{SL}_{1}\right)_{2}\right]$ : Dark green solid; yield $=85.07 \%$; $\mathrm{mp}:>300^{\circ} \mathrm{C}$. Molecular formula $\left(\mathrm{CoC}_{28} \mathrm{H}_{18} \mathrm{~N}_{2} \mathrm{O}_{4} \mathrm{~S}_{2}\right.$ ), m/z: 570.00 (Mol. Wt.: $569.52 \mathrm{~g} / \mathrm{mol}$ ). Elemental analysis: Calculated (found) \%C $58.84 \quad(59.20) ; \% \mathrm{H}$ 3.53 (3.76); \%N 4.90 (5.10); \%O 11.20 (11.57); \%S 11.20 (11.16); \%Co $10.32(10.63)$.

[Fe( $\left.\left(\mathrm{SL}_{2}\right)_{2}\right]$ : Dark brown solid; yield $=98.96 \%$; $\mathrm{mp}:>300^{\circ} \mathrm{C}$. Molecular formula $\left(\mathrm{FeC}_{34} \mathrm{H}_{22} \mathrm{~N}_{2} \mathrm{O}_{2} \mathrm{~S}_{2}\right.$ ), m/z: 610.53 (Mol. Wt.: $611.23 \mathrm{~g} / \mathrm{mol}$ ). Elemental analysis: Calculated (found) \%C $66.67 \quad(67.00) ; \% \mathrm{H}$ 3.95 (4.22); \%N 4.58 (4.34); \%O 5.23 (5.65); \%S 10.45 (10.84); \% Fe $9.13(9.50)$.

$\left[\mathrm{Ni}\left(\mathrm{SL}_{2}\right)_{2}\right]$ : Brown solid; yield $=97.13 \% ; \mathrm{mp}:>300^{\circ} \mathrm{C}$. Molecular formula $\left(\mathrm{NiC}_{34} \mathrm{H}_{22} \mathrm{~N}_{2} \mathrm{O}_{2} \mathrm{~S}_{2}\right.$ ), m/z: 613.25 (Mol. Wt.: $613.37 \mathrm{~g} / \mathrm{mol}$ ). Elemental analysis: Calculated (found) \%C 66.36 (65.90); \%H 3.93 (4.23); \%N 4.56 (4.15); \%0 5.20 (5.00); \%S 10.40 (10.72); \%Ni 9.55 (9.50).

$\left[\mathrm{Co}\left(\mathrm{SL}_{2}\right)_{2}\right]$ : Dark brown solid; yield $=95.57 \%$; $\mathrm{mp}:>300^{\circ} \mathrm{C}$. Molecular formula $\left(\mathrm{CoC}_{34} \mathrm{H}_{22} \mathrm{~N}_{2} \mathrm{O}_{2} \mathrm{~S}_{2}\right.$ ), m/z: 613.92 (Mol. Wt.: $613.61 \mathrm{~g} / \mathrm{mol}$ ). Elemental analysis: Calculated (found) \%C 66.33 (65.96); \%H 3.93 (4.25); \%N 4.55 (4.30); \%O 5.20 (5.58); \%S 10.40 (10.12); \%Co $9.58(9.61)$.

$\left[\mathrm{Fe}\left(\mathrm{SL}_{3}\right)_{2}\right]$ : Brown solid; yield $=82.45 \%$; $\mathrm{mp}:>300^{\circ} \mathrm{C}$. Molecular formula $\left(\mathrm{FeC}_{32} \mathrm{H}_{20} \mathrm{~N}_{4} \mathrm{O}_{2} \mathrm{~S}_{2}\right.$ ), m/z: 612.25 (Mol. Wt.: $612.25 \mathrm{~g} / \mathrm{mol}$ ). Elemental analysis: Calculated (found) \%C $62.54(62.37) ; \% \mathrm{H} 3.61(3.96) ; \% \mathrm{~N}$ 9.12 (8.85); \%0 5.21 (5.41); \%S 10.42 (10.79); \%Fe 9.10 (8.82).

$\left[\mathrm{Ni}\left(\mathrm{SL}_{3}\right)_{2}\right]$ : Light brown solid; yield $=79.80 \% ; \mathrm{mp}:>300^{\circ} \mathrm{C}$. Molecular formula $\left(\mathrm{NiC}_{32} \mathrm{H}_{20} \mathrm{~N}_{4} \mathrm{O}_{2} \mathrm{~S}_{2}\right.$ ), m/z: 615.76 (Mol. Wt.: $615.35 \mathrm{~g} / \mathrm{mol}$ ). Elemental analysis: Calculated (found) \%C 62.26 (62.20); \%H 3.59 (3.66); \%N 9.08 (9.23); \%0 5.19 (5.68); \%S 10.37 (10.13); \%Ni 9.52 (9.16).

$\left[\mathrm{Co}\left(\mathrm{SL}_{3}\right)_{2}\right]$ : Brown solid; yield $=82.65 \%$; $\mathrm{mp}:>300^{\circ} \mathrm{C}$. Molecular formula $\left(\mathrm{CoC}_{32} \mathrm{H}_{20} \mathrm{~N}_{4} \mathrm{O}_{2} \mathrm{~S}_{2}\right.$ ), m/z: 614.84 (Mol. Wt.: $615.59 \mathrm{~g} / \mathrm{mol}$ ). Elemental analysis: Calculated (found) \%C $62.23(61.95) ; \% \mathrm{H} 3.95(4.10) ; \% \mathrm{~N}$ 9.08 (8.76); \%0 5.18 (5.43); \%S 10.36 (10.64); \%Co 9.55 (10.09).

In vitro antibacterial and antifungal activity experimentation In this investigation, the prepared Schiff base compounds and their corresponding metal complexes were examined for the antibacterial and antifungal activity. The experiments were performed in vitro at the Department of Clinical Microbiology, Blood Bank Center, Al-Baha city. The antibacterial investigation for the prepared Schiff base ligands and their respective metal complexes were assayed against three types of Gram-positive and three Gram-negative bacterial strains. The Grampositive bacterial strains used were Staphylococcus epidermidis (ATCC 12228), Staphylococcus aureus (ATCC 25923), and Enterococcus faecalis (ATCC 29212). The three Gram-negative bacterial strains Pseudomonas aeruginosa (ATCC 27853), Escherichia coli (ATCC 25922), and Proteus mirabilis (ATCC 13376) were used in this investigation. The common pathogenic fungal strain Candida albicans (ATCC 10231) was used for antifungal tests. Mueller-Hinton agar was used as the growth medium for bacterial strains, and Sabouraud Dextrose Agar was used as culture 
medium for fungus yeast. Disk-diffusion agar assessment technique was followed according to the Clinical and Laboratory Standards Institute susceptibility testing technique [25].

Stock solutions of the tested compounds were prepared by dissolving $0.01 \mathrm{~g}$ of each compound in $5 \mathrm{~mL}$ DMSO solvent. Amoxicillin antibacterial drug was used as a reference for comparison.

Whatman sterilized $6 \mathrm{~mm}$ filter paper discs (Whatman antibiotic assay discs - model 2017-006 from Sigma-Aldrich) containing the tested compounds were placed on the agar surface in Petri dishes where the microorganisms were spread and allowed to grow on the agar media. The Petri dishes were put in an incubator at $37^{\circ} \mathrm{C}$ for $36 \mathrm{~h}$ in the case of bacteria and at $35^{\circ} \mathrm{C}$ for $48 \mathrm{~h}$ for fungus. The effectiveness of each compound was measured using zones of complete inhibition (in $\mathrm{mm}$ ) after the incubation period to monitor the fungal and bacterial susceptibilities. Each test was repeated twice, and the arithmetic mean values were recorded

In addition, the minimum inhibitory concentration (MIC) values of the compound $\left[\mathrm{Co}\left(\mathrm{SL}_{3}\right)_{2}\right]$ that showed the highest activity against E. faecalis bacterial strain were investigated. Agar disk-diffusion assay was used for MIC tests following the European Committee on Antimicrobial Susceptibility Testing standards [26]. Decreasing concentrations were prepared in serial two-fold dilution $100,50,25,12.5,6.25$, and $3.125 \mu \mathrm{g} /$ disc for each tested compound which were used for the MIC investigations. Each sample was repeated twice, and arithmetic mean values were recorded.

\section{In vivo molluscicidal activity of the prepared compounds}

The obtained Schiff base ligands and their corresponding metal complexes were tested for their molluscicidal activity according to the standard reported methods, as cited in the literature [14,26,27]. The solutions of the compounds used for the bioassay were prepared with concentrations ranging from (50 ppm, 100 ppm, 500 ppm, 1000 ppm, and $5000 \mathrm{ppm}$ ) in DMSO solvent.

The snails (30 in number) used in this investigation were water snails named Biomphalaria arabica. The snails were collected from Wadis and near the water reservoirs at the local Al-Baha city area using traps with longhand and transferred immediately to the laboratory using clean plastic bags containing sufficient amount of water from the same source. The snails were reared for enough periods to acclimatize with laboratory conditions before assessment. The snails were divided into groups and each group of five snails. The snails were maintained at room temperature nearly $24^{\circ} \mathrm{C}$ in plastic tanks $(30 \mathrm{~cm} \times 15 \mathrm{~cm} \times 10 \mathrm{~cm})$ containing some sand and freshwater (bottle water) with neutral $\mathrm{pH}$ and fed with commercial fish food and some green lettuce leaves. The water in the tank was replaced every 2 days.

Molluscicidal activity evaluation of the tested compounds was performed by observing the toxicity and lethal dose $\left(\mathrm{LD}_{50}\right)$ according to the WHO guidelines using the immersion technique and using niclosamide as a control measure [27].

The reared snails were immersed in a mixed aqueous solution of the investigated compounds at the final concentrations for $24 \mathrm{~h}$ without food. After exposure to the tested compounds, the snails were transferred to freshwater without fed for another $24 \mathrm{~h}$ as a recovery period to assess mortality. The mortality was determined after $24 \mathrm{~h}$ and the $50 \%\left(\mathrm{LC}_{50}\right.$ ) lethal concentration was determined. Each molluscicidal experiment was repeated in duplicate for each compound and dose-effect evaluation was done using the Litchfield and Wilcoxon method [28].

\section{RESULTS AND DISCUSSION}

All the prepared Schiff base ligands and their corresponding Co, Fe, and Ni metal complexes were analyzed and characterized by various physical and spectroscopic analytical techniques using mass spectra, micro-elemental analysis, FT-IR, UV-visible, ${ }^{1} \mathrm{H}$ NMR, ${ }^{13} \mathrm{C}$ NMR, magnetic susceptibility, conductivity, and TGA to prove the composition and structure elucidation of the synthesized compounds.

\section{Chemistry, elemental analysis, and mass spectra}

The Schiff base ligands designed in this project were synthesized following standard reported procedures, as described in the previous section materials and methods. For preparing the tailored asymmetrical tridentate Schiff base ligands $\left(\mathrm{SL}_{1}-\mathrm{SL}_{3}\right)$, we used 2-aminothiophenol as primary amine and was condensed with 2-carboxybenzaldehyde, 2-hydroxy-1-naphthaldehyde, and 7-formyl-8-hydroxyquinoline as carbonyl compounds. The stoichiometric reaction ratio for the primary amine to the aldehydic compound was 1:1. The synthesized Schiff bases were purified by recrystallization and were in good yields. They were colored and most of them were soluble in hot ethanol, chloroform, DMF, and DMSO.

The isolated asymmetrical Schiff base ligands were characterized, and structures were confirmed before proceeding for the preparation of the metal complexes step. The elemental analysis and mass spectral analysis (shown in the experimental section) were in good agreement with the theoretically calculated percentage values for the proposed molecular formulae and hence confirmed and prove the expected structures of the synthesized asymmetric Schiff base ligands.

\section{Preparation of metal complexes}

In this investigation, we selected the iron triad transition metals (iron, cobalt, and nickel) for preparation of the tailored metal complexes The iron triad metals were selected because they show similarity among themselves in physical and chemical properties and are adjacent to each other in the first series of the d-block elements (4-day period in the periodic table).

The targeted metal complexes were synthesized using the prepared unsymmetrical tridentate Schiff base ligands successfully according to the template method, as mentioned before in the materials and methods section.

The different metal complexes produced were non-hygroscopic colored amorphous solids, stable at room temperature, and in good yields. They were purified by recrystallization from hot DMF and DMSO solvents. The metal complexes obtained were insoluble in common organic solvents and only soluble in hot DMF and DMSO solvents. The molecular formulae, molecular weights, mass spectra, elemental analysis, colors, and yields are presented in the experimental section. All synthesized complexes decomposed without melting at high temperatures above $300^{\circ} \mathrm{C}$.

The suggested structures of the metal complex compounds were formed in (1:2) metal:ligand stoichiometric ratio. The elemental analysis, as observed in the experimental section, revealed good agreement with the proposed structures. The asymmetrical tridentate ligands $\left(\mathrm{SL}_{1}, \mathrm{SL}_{2}\right.$, and $\mathrm{SL}_{3}$ ) form hexa-coordinate monomeric Fe(III), Ni(II), and Co(II) complexes corresponding to the complexes general formula [M(SL) $\left.{ }_{2}\right]$ (Fig. 1).

The coordinated atoms of the ligand are symmetrically arranged around the central metal atom in the complexes. The ligands bind to the metal atom through the usual nitrogen donor atom of the azomethine group, sulfur atom of the thiol group, and oxygen atom of the carboxylic group or the phenolic group forming octahedral geometry around the metal atom.

In addition, the mass spectra of the synthesized complexes were carried out to determine and confirm the molecular weights. The synthesized metal complexes showed the ion molecular $(\mathrm{m} / \mathrm{z})$ peaks corresponding to the proposed molecular formula and in agreement with the calculated molecular weights of the metal complexes. 


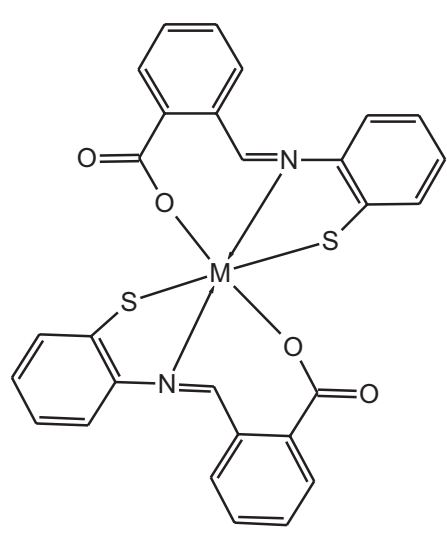

a

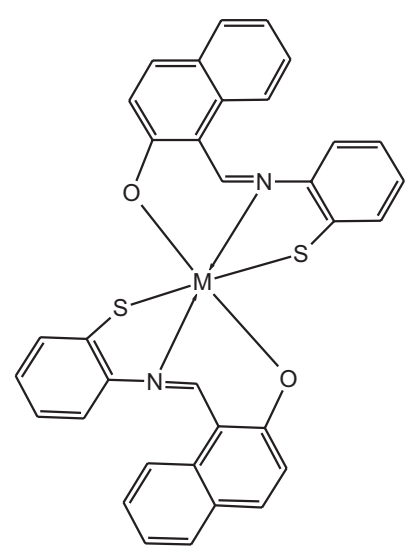

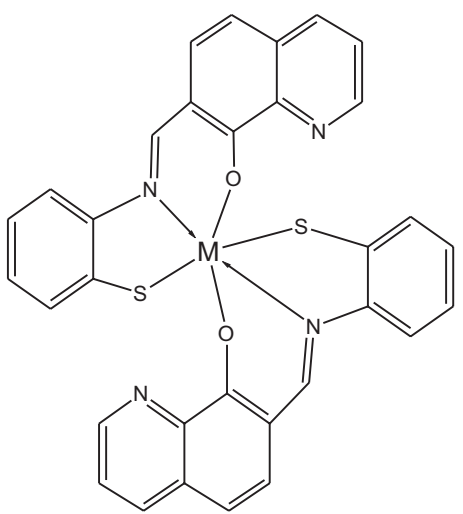

b c

Fig. 1: Chemical structures for metal complexes (M = Fe(III), Ni(II), and Co(II)) (a) $\left[\mathrm{M}\left(\mathrm{SL}_{1}\right)_{2}\right],(\mathrm{b})\left[\mathrm{M}\left(\mathrm{SL}_{2}\right)_{2}\right],(\mathrm{c})\left[\mathrm{M}\left(\mathrm{SL}_{3}\right)_{2}\right]$

\section{Spectral properties}

UV-visible spectra and magnetic moment measurements

The UV-visible spectral data of the ligands and their corresponding iron, cobalt, and nickel complexes were recorded in the DMSO solution with a concentration of $10^{-3} \mathrm{M}$. The nature of the ligand field around the central metal ions has been estimated from the UV-visible spectra and supported by magnetic moment measurements the metal complexes.

The UV-visible absorption spectra of the free Schiff base ligands exhibit two bands in the range of $253-285 \mathrm{~nm}$ and $325-370 \mathrm{~nm}$ assignable to the transitions $\pi \rightarrow \pi^{*}$ of the benzene ring and $n \rightarrow \pi^{*}$ transitions of the $(>\mathrm{C}=\mathrm{N}-$ ) group, respectively $[29,30]$.

The absorption spectra of some analyzed metal complexes of Co(II), $\mathrm{Fe}(\mathrm{III})$, and $\mathrm{Ni}(\mathrm{II})$ complexes have exhibited bands at lower intensities and longer wavelength compared to those of the free Schiff base ligands. This bathochromic shift (redshift) may be due to the coordination of the nitrogen atom of the azomethine group and other atoms with the metal ion $[10,31]$.

The absorption spectra of the metal complexes display a weak band shoulder appeared in the range of 470-490 nm, which may be attributed to the ligand to metal-charge transfer transitions that expected for complexes of metals with low oxidation state [29]. This charge transfer band is a result of the formation of the coordination bond between the metal ion and the ligands that causes a change in electron distribution between the ligand and the metal ion. The d-d transitions were not observed since they are perturbed by the broad charge transfer transitions [32]. The discussion for each metal complexes is given below.

\section{Co(II) complexes}

The UV-visible spectrum of the brown Co(II) complexes obtained from the unsymmetrical Schiff base ligands showed three bands appeared at a range around 995-1010, 625-660, and 510-530 $\mathrm{nm}$ that may be assigned to the transitions ${ }^{4} \mathrm{~T}_{1} \mathrm{~g} \rightarrow{ }^{4} \mathrm{~T}_{2} \mathrm{~g},{ }^{4} \mathrm{~T}_{1} \mathrm{~g} \rightarrow{ }^{4} \mathrm{~A}_{2} \mathrm{~g}$, and ${ }^{4} \mathrm{~T}_{1} \mathrm{~g} \rightarrow{ }^{4} \mathrm{~T}_{1} \mathrm{~g}$, respectively. These transitions indicated that the $\mathrm{Co}$ (II) ion is in the field of octahedral geometry [33-35]. The magnetic moment measurements of some cobalt complexes were in the range of 4.15-4.45 B.M., which is a paramagnetic behavior and supporting the high-spin octahedral geometry $[35,36]$.

\section{Fe(III) complexes}

Fe(III) complex compounds obtained from the asymmetrical Schiff base ligands $\left(\mathrm{SL}_{1}, \mathrm{SL}_{2}\right.$, and $\mathrm{SL}_{3}$ ) showed three low-intensity absorption bands at around 630-655, 585-593, and 540-550 nm in the UV-visible spectrum. These bands suggesting an octahedral geometry around the iron atom in the complexes [35,37]. This also was supported by the magnetic moment measurement values of 5.38-5.44 B.M that is confirming high-spin state $[35,38]$. Hexa-coordinated $d^{5}$-iron(III) complexes with Schiff base ligands are known to display a variety of magnetic behavior [16].

\section{$\mathrm{Ni}(\mathrm{II})$ complexes}

The UV-visible spectrum of Nickel(II) complex compounds obtained from the unsymmetrical Schiff base ligands $\left(\mathrm{SL}_{1}, \mathrm{SL}_{2}\right.$, and $\left.\mathrm{SL}_{3}\right)$ gave three bands at 960-985, 545-550, and 410-425 $\mathrm{nm}$ in the UV-visible spectrum. These bands pointed out to ${ }^{3} \mathrm{~A}_{2} \mathrm{~g} \rightarrow{ }^{3} \mathrm{~T}_{2} \mathrm{~g},{ }^{3} \mathrm{~A}_{2} \mathrm{~g} \rightarrow{ }^{3} \mathrm{~T} \mathrm{~g}$, and ${ }^{3} \mathrm{~A}_{2} \mathrm{~g} \rightarrow{ }^{3} \mathrm{~T}_{1} \mathrm{~g}$ transitions, respectively, suggesting an octahedral geometry around the $\mathrm{Ni}$ atom in the complexes. This suggestion was supported by the magnetic moment measurement values of 3.42-3.56 B.M [33,34,39].

\section{FT-IR spectral analysis}

IR spectra of the organic Schiff bases

The IR spectra of the prepared unsymmetrical organic Schiff base compounds showed guide peaks and main characteristic bands in the recorded IR spectra that were of good assist for characterizing the ligands. The characteristic wide band in the spectra of the different prepared Schiff base ligands appeared in the range of 1553$1560 \mathrm{~cm}^{-1}$ was assigned to the characteristic azomethine ( $>\mathrm{CH}==\mathrm{N}-$ ) group indicating the formation of the required Schiff base ligands [2]. The total absence of $v_{\mathrm{C}=0}$ band of the coupled aldehydes precursors in the IR spectra of ligands together clearly indicates that a Schiff base has formed in each case.

The band appeared in the range of $2567-2583 \mathrm{~cm}^{-1}$ in all asymmetric Schiff base ligands $\left(\mathrm{SL}_{1}, \mathrm{SL}_{2}\right.$, and $\left.\mathrm{SL}_{3}\right)$ was assigned to the thiol $(-\mathrm{SH})$ group [33], while the medium bands observed at $1575 \mathrm{~cm}^{-1}$ and $1370 \mathrm{~cm}^{-1}$ in the spectrum of the ligand $\mathrm{SL}_{1}$ were due to the $v_{\text {asym }}\left(\mathrm{COO}^{-}\right)$and $v_{\text {sym }}\left(\mathrm{COO}^{-}\right)$carboxylate group stretching vibrations, respectively [40]. The band observed in the range of $3350-3455 \mathrm{~cm}^{-1}$ in the spectrum of the ligand $\mathrm{SL}_{1}$ may be assigned to the $\mathrm{vOH}$ of the carboxylic group [40]. Furthermore, the wide bands appeared in the range of $3279.9-3420 \mathrm{~cm}^{-1}$ in the IR spectrum of the $\mathrm{SL}_{2}$ and $\mathrm{SL}_{3}$ Schiff base ligands were assigned to the stretching vibration of phenolic $(-\mathrm{OH})$ group [33].

\section{IR spectra of the coordination metal complexes}

The IR spectra of the ligands and their corresponding metal complexes provide information about the metal-ligand bonding. The IR spectra of the metal complexes showed that the characteristic azomethine band that appeared at the range of $1553-1560 \mathrm{~cm}^{-1}$ in the spectrum of the organic Schiff base ligands was shifted to lower/higher wavenumber in the spectra of the metal complexes (1504-1597.7 $\mathrm{cm}^{-1}$ ) compared with the parent ligands. This phenomenon proves the coordination of the 
nitrogen atom of the azomethine group to the metal ions [40]. This also was supported by the appearance of a new band at $450-485 \mathrm{~cm}^{-1}$ due to the coordination bond $\left(v_{\mathrm{M}-\mathrm{N}}\right)$ in the IR spectrum of the metal complexes.

The bands exhibited due to the asymmetric and symmetric carboxylate group in $\mathrm{SL}_{1}$ ligand were shifted to $1442-1490 \mathrm{~cm}^{-1}$ and $1330-$ $1378 \mathrm{~cm}^{-1}$ in the spectra of different metal complexes of this ligand. In addition, the band due to the $v_{\text {он }}$ of the carboxylate group showed a shift in the spectrum of the metal complexes of the $\mathrm{SL}_{1}$ ligand. This shift in positions indicates the involvement of the carboxylate group of $\mathrm{SL}_{1}$ ligand in chelation and involvement of $\mathrm{COOH}$ group in intermolecular hydrogen bond formation $[34,41]$. There is a band observed at $1760-$ $1770 \mathrm{~cm}^{-1}$ in the spectra of the $\mathrm{SL}_{1}$ metal complexes, which can be assigned to the $v_{\mathrm{C}=0}$ of the carboxylic group [34]. This band was also observed at $1765 \mathrm{~cm}^{-1}$ in the spectrum of the $\mathrm{SL}_{1}$ Schiff base ligand. This means that it is nearly at the same position indicating noninvolvement of this $\mathrm{C}=\mathrm{O}$ of the carboxylic group in coordination to metal ions. The band due to - $\mathrm{SH}$ group in the $\mathrm{SL}_{1}, \mathrm{SL}_{2}$, and $\mathrm{SL}_{3}$ ligands was disappeared in the spectrum of the metal complexes. The IR spectrum of the metal complexes of these ligands showed the occurrence of new bands in the range $430-450 \mathrm{~cm}^{-1}$ that may be assigned to $v_{\mathrm{M}-\mathrm{S}}$ mode provided an evidence for the bonding of sulfur atom to the metal ions [33].

These bands due to the stretching vibration of phenolic $v_{\mathrm{OH}}$ appeared in the spectra of the Schiff base ligands were disappeared in the IR spectra of the corresponding metal complexes indicating the participation of oxygen atom of the phenolic group in bonding with the metal atom. Moreover, a medium band was observed in the metal complexes in the range of 503-536 cm-1, which can be assigned to the $v_{\mathrm{M}-0}$ mode $[2,42]$. Therefore, it can be concluded that the asymmetric Schiff base ligands $\mathrm{SL}_{1}, \mathrm{SL}_{2}$, and $\mathrm{SL}_{3}$ behave as tridentate ligands. These ligands are coordinated to the metal ions through nitrogen atom of the azomethine group, oxygen atom of the carboxylate group (in case of $\mathrm{SL}_{1}$ ) or the oxygen atom of the phenolic group (in case of $\mathrm{SL}_{2}$ and $\mathrm{SL}_{3}$ ) and the sulfur atom of the thiol group.

\section{${ }^{1} \mathrm{H}$ and ${ }^{13} \mathrm{C}$ NMR spectra}

The ${ }^{1} \mathrm{H}$ and ${ }^{13} \mathrm{C}$ NMR spectra analysis was carried out for some prepared Schiff bases and their respective metal complexes due to the high cost of analysis and the inconvenience.

In the ${ }^{1} \mathrm{H}$ NMR spectra of the three ligands, a sharp singlet appeared at $8.39 \mathrm{ppm}$ due to the azomethine protons $(\mathrm{CH}=\mathrm{N})$ and confirmed its formation [43]. In the metal complex, this signal was shifted to 8.02-8.27 ppm, indicating the involvement of the azomethine group in chelation. Moreover, the signals of singlet at $11 \mathrm{ppm}$ (in case of $\mathrm{SL}_{1}$ ) and $13.2 \mathrm{ppm}$ (in case of $\mathrm{SL}_{2}$ and $\mathrm{SL}_{3}$ ) confirmed the presence of phenolic - $\mathrm{OH}$ protons in the Schiff base ligands and were not observed in the metal complexes. Furthermore, the signals of singlet at $3.2 \mathrm{ppm}$ for $\mathrm{SL}_{1}$ and $3.75 \mathrm{ppm}$ for $\mathrm{SL}_{2}$ are assigned to thiol group protons in the ligands and were absent in the metal Schiff base complexes. The absence of resonance due to $\mathrm{OH} / \mathrm{SH}$ protons in the coordination compounds indicating the deprotonation of the hydroxyl and the thiol groups in the asymmetric ligands and the coordination of the oxygen and the sulfur atoms to the metal atoms $[43,44]$. The multiplets in $\delta$ $6.92-7.29 \mathrm{ppm}$ and 7.31-8.21 ppm regions are assigned to the protons of benzylidene ring groups. All of the protons were found to be in their expected regions and numbers.

The ${ }^{13} \mathrm{C}$ NMR spectra of the ligands showed peaks at the range of 109.51-139.22 ppm and 118.49-129.78 ppm regions, which were assignable to the carbons of the aromatic rings. The signal at $168.52 \mathrm{ppm}$ can be assigned for the carbonyl group of ligand $\mathrm{SL}_{1}$. The $\mathrm{HC}=\mathrm{N}$ carbon resonance is observed at $143.07,166.66$, and $164.98 \mathrm{ppm}$ in the spectrum of $\mathrm{SL}_{1}, \mathrm{SL}_{2}$, and $\mathrm{SL}_{3}$, respectively [30]. This carbon was shifted to the downfield approximately $5 \mathrm{ppm}$ relative to the free ligands confirming the transfer of one lone pair electron from nitrogen to metal and coordination of azomethine-N to metal.

\section{Thermal studies}

The simultaneous TGA and differential thermal analysis (DTA) of metal complexes were studied from ambient temperature at $1000^{\circ} \mathrm{C}$ in a nitrogen atmosphere. This TGA and DTA analyses are carried out to support the proposed structures for the synthesized metal complexes. The correlation between the different decomposition steps of metal complexes with corresponding weight losses is discussed in terms of the proposed formula of the metal complexes. Some $\mathrm{Co}(\mathrm{II}), \mathrm{Ni}(\mathrm{II})$, and $\mathrm{Fe}(\mathrm{III})$ complexes of the asymmetric ligands $\mathrm{SL}_{1}$ and $\mathrm{SL}_{2}$ were selected for thermal studies. The thermogram of the selected Schiff base complexes is depicted in Figs. 2-7.

The effect of the heating rate on the thermal decomposition process notes are summarized in the following points:

- The TG curve of $\left[\mathrm{Co}\left(\mathrm{SL}_{1}\right)_{2}\right]$ complex first shows a slow decomposition from 140 to $360^{\circ} \mathrm{C}$, with $47.29 \%$ (calcd. $45.18 \%$ ) mass loss, a broad

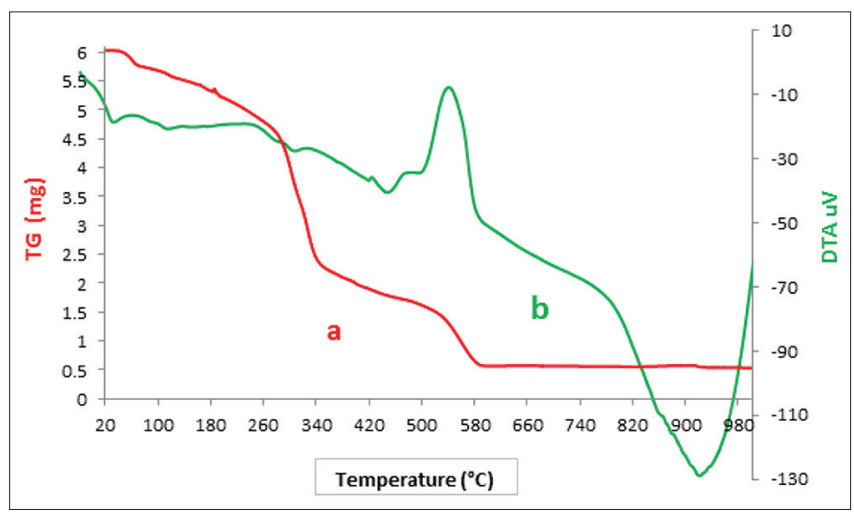

Fig. 2: (a) Thermogravimetric and (b) differential thermal analysis curves of $\left[\mathrm{Co}\left(\mathrm{SL}_{1}\right)_{2}\right]$

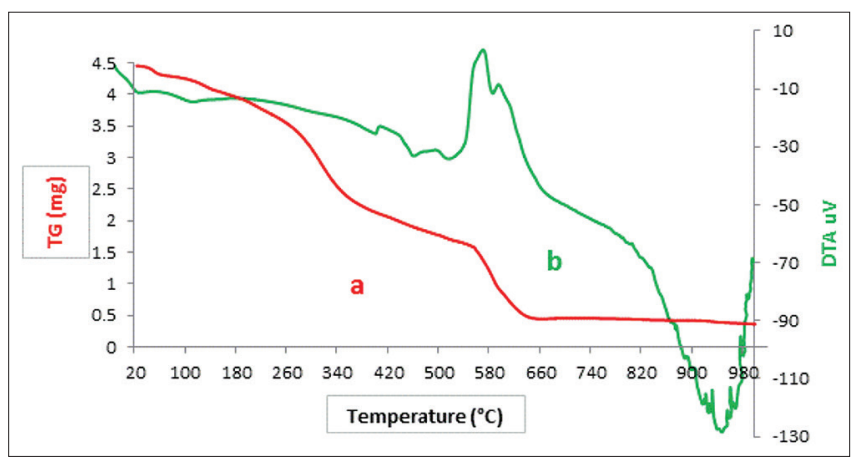

Fig. 3: (a) Thermogravimetric and (b) differential thermal analysis curves of $\left[\mathrm{Co}\left(\mathrm{SL}_{2}\right)_{2}\right]$

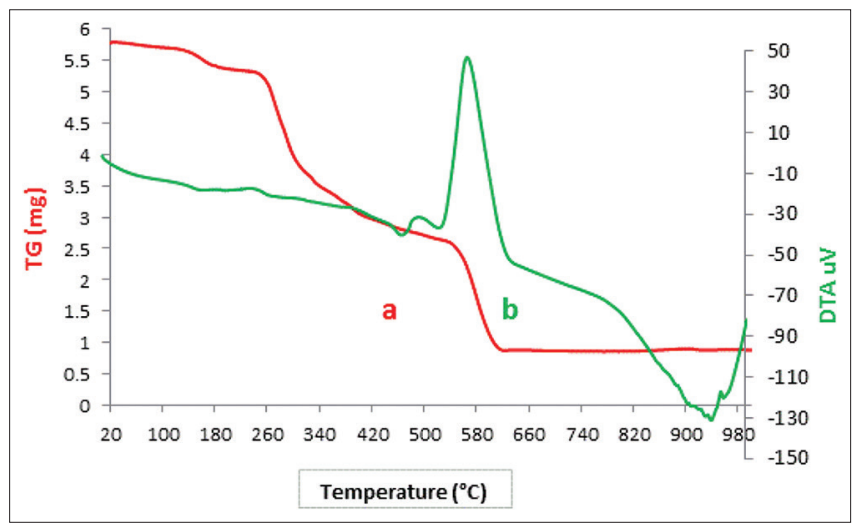

Fig. 4: (a) Thermogravimetric and (b) differential thermal analysis curves of $\left[\mathrm{CoSL}_{5}\right]$ 


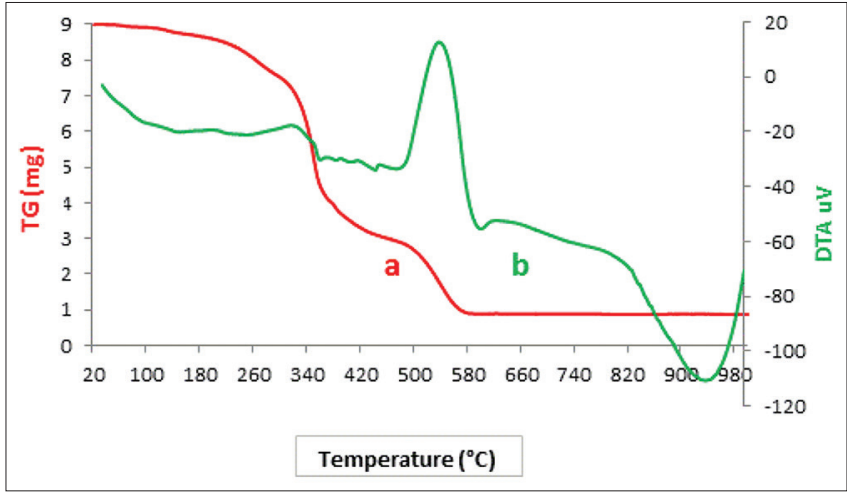

Fig. 5: (a) Thermogravimetric and (b) differential thermal analysis curves of $\left[\mathrm{Fe}\left(\mathrm{SL}_{1}\right)_{2}\right]$

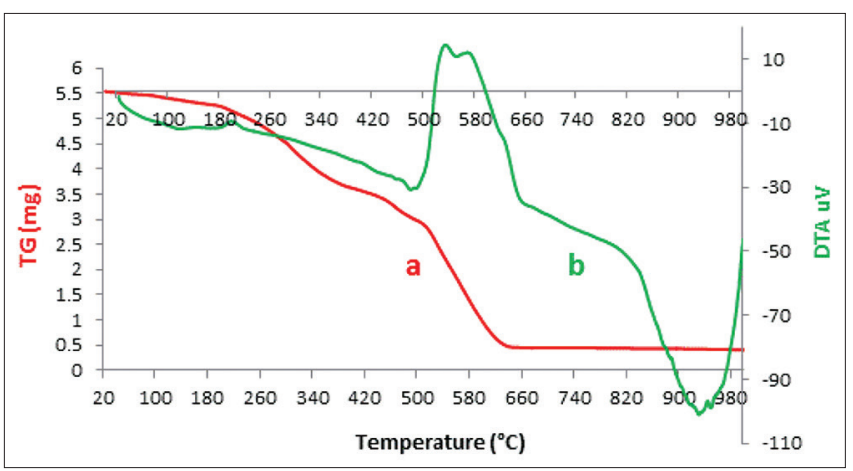

Fig. 6: (a) Thermogravimetric and (b) differential thermal analysis curves of $\left[\mathrm{Fe}\left(\mathrm{SL}_{2}\right)_{2}\right]$

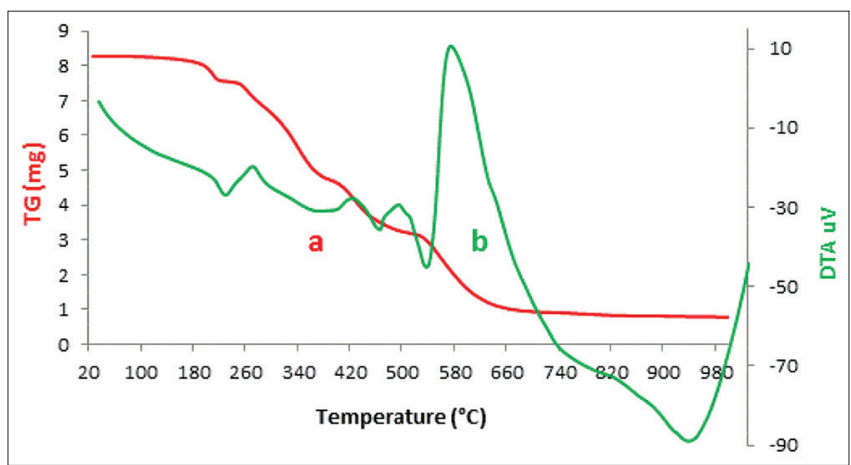

Fig. 7: (a) Thermogravimetric and (b) differential thermal analysis curves of $\left[\mathrm{Ni}\left(\mathrm{SL}_{2}\right)_{2}\right]$

exothermic peak at $\Delta \mathrm{T}_{\max }=255^{\circ} \mathrm{C}$ in DTA may be attributed to the removal of ligand $\mathrm{SL}_{1}$. The second step decomposition is from 440 to $620^{\circ} \mathrm{C}$, a sharp exothermic in DTA at $550^{\circ} \mathrm{C}$ is observed for this step. The mass of final residue corresponds to stable $\mathrm{CoO}_{2}(16.84 \%)$ (calcd. 15.96\%)

- The TG curve of $\left[\mathrm{Co}\left(\mathrm{SL}_{2}\right)_{2}\right]$ complex first shows a slow decomposition from 120 to $360^{\circ} \mathrm{C}$, with $45.10 \%$ (calcd. $45.51 \%$ ) mass loss, a broad exothermic peak at $\Delta \mathrm{T}_{\text {max }}=250^{\circ} \mathrm{C}$ in DTA may be attributed to the removal of ligand $\mathrm{SL}_{2}$. The second step decomposition is from 440 to $640^{\circ} \mathrm{C}$, a sharp exothermic peak in DTA at $575^{\circ} \mathrm{C}$ is observed for this step. The mass of final residue corresponds to stable $\mathrm{Co}_{2} \mathrm{O}_{3^{\prime}}$ (28.31\%) (calcd. 27.01\%)

- The TG curve of $\left[\mathrm{Fe}\left(\mathrm{SL}_{1}\right)_{2}\right]$ complex first shows a slow decomposition from 160 to $380^{\circ} \mathrm{C}$, with $46.02 \%$ (calcd. $45.42 \%$ ) mass loss, a broad exothermic peak at $\Delta \mathrm{T}=295^{\circ} \mathrm{C}$ in DTA may be attributed to the removal of ligand $\mathrm{SL}_{1}$. The second step decomposition is from 440 to $580^{\circ} \mathrm{C}$, a sharp exothermic in DTA at $525^{\circ} \mathrm{C}$ is observed for this
Table 1: The recorded molar conductivity of the prepared complexes

\begin{tabular}{ll}
\hline Metal complex & Molar conductivity $\left(\mathbf{S ~ c m}^{2} \mathbf{~ m o l}\right)$ \\
\hline$\left[\mathrm{Fe}\left(\mathrm{SL}_{1}\right)_{2}\right]$ & 43.2 \\
{$\left[\mathrm{Ni}\left(\mathrm{SL}_{1}\right)_{2}\right]$} & 9.37 \\
{$\left[\mathrm{Co}\left(\mathrm{SL}_{1}\right)_{2}\right]$} & 16.4 \\
{$\left[\mathrm{Fe}\left(\mathrm{SL}_{2}\right)_{2}\right]$} & 64.5 \\
{$\left[\mathrm{Ni}\left(\mathrm{SL}_{2}\right)_{2}\right]$} & 5.77 \\
{$\left[\mathrm{Co}\left(\mathrm{SL}_{2}\right)_{2}\right.$} & 27.7 \\
{$\left[\mathrm{Fe}\left(\mathrm{SL}_{3}\right)_{2}\right]$} & 63.56 \\
{$\left[\mathrm{Ni}\left(\mathrm{SL}_{3}\right)_{2}\right]$} & 2.35 \\
{$\left[\mathrm{Co}\left(\mathrm{SL}_{3}\right)_{2}\right.$} & 18.5 \\
\hline
\end{tabular}

step. The mass of final residue corresponds to stable $\mathrm{Fe}_{2} \mathrm{O}_{3^{\prime}},(26.11 \%)$ (calcd. 26.15\%)

- The TG curve of $\left[\mathrm{Fe}\left(\mathrm{SL}_{2}\right)_{2}\right]$ complex first shows a slow decomposition from 120 to $370^{\circ} \mathrm{C}$, with $21.00 \%$ (calcd. $23.44 \%$ ) mass loss, a broad exothermic peak at $\Delta \mathrm{T}_{\max }=250^{\circ} \mathrm{C}$ in DTA may be attributed to the removal of the coordinate part of ligand $\mathrm{SL}_{2}$. The second step decomposition is from 430 to $640^{\circ} \mathrm{C}$, two sharp exothermic peaks in DTA, at 525 and $550^{\circ} \mathrm{C}$, are observed for this step. The mass of final residue corresponds to a stable mixture of $\mathrm{FeO}$ and $\mathrm{Fe}_{3} \mathrm{O}_{4,}(49.9268 \%)$ (calcd. 50.70\%)

- The TG curve of $\left[\mathrm{Ni}\left(\mathrm{SL}_{2}\right)_{2}\right]$ complex first shows a slow decomposition from 120 to $380^{\circ} \mathrm{C}$, with $42.15 \%$ (calcd. $45.54 \%$ ) mass loss, a broad exothermic peak at $\Delta \mathrm{T}_{\text {max }}=240^{\circ} \mathrm{C}$ in DTA may be attributed to the removal of ligand $\mathrm{SL}_{2}$. The second step decomposition is from 460 to $640^{\circ} \mathrm{C}$, a sharp exothermic peak in DTA at $550^{\circ} \mathrm{C}$ is observed for this step. The mass of final residue corresponds to stable $\mathrm{Ni}_{2} \mathrm{O}_{3^{\prime}},(30.18 \%)$ (calcd. 29.96\%)

\section{Molar conductivity behavior}

The molar conductivity measurements (Table 1 ) of the prepared metal complexes were measured in the DMSO solution of $10^{-3} \mathrm{M}$ concentration to establish the ionic nature of the complexes. The DMSO solvent was selected because all complexes are soluble at room temperature $22.4^{\circ} \mathrm{C}$. The molar conductance observation results showed variety and low molar conductivity values $\left(2.35-64.5 \mathrm{~S} \mathrm{~cm}^{2} / \mathrm{mol}\right)$ consistent with non-electrolytic behavior and so they are non-ionic in nature and that the anionic ligand is coordinated to the central metal ion $[45,46]$. The relatively high values 64.5 and $63.56 \mathrm{~S} \mathrm{~cm}^{2} / \mathrm{mol}$ for complexes $\left[\mathrm{Fe}\left(\mathrm{SL}_{2}\right)_{2}\right]$ and $\left[\mathrm{Fe}\left(\mathrm{SL}_{3}\right)_{2}\right]$, respectively, may be due to partial solvolysis in DMSO [47].

\section{In vitro antimicrobial assay}

In this paper, the prepared unsymmetrical Schiff base ligands along with their Fe(III), Ni(II), and Co(II) metal complexes were screened in vitro for their antimicrobial potential against three Gram-positive and three Gram-negative bacterial strains and one fungal strain as mentioned in the materials and methods section. Agar disk-diffusion assay technique was used in experimentation to assess the antibacterial and antifungal activities of the synthesized compounds [48]. The results of the experiments are presented in Table 2.

The examined asymmetrical organic Schiff base ligands $\left(\mathrm{SL}_{1}, \mathrm{SL}_{2}\right.$, and $\left.\mathrm{SL}_{3}\right)$ showed low antibacterial activity against the Gram-positive bacterial types with zones of inhibitions $<15 \mathrm{~mm}$ while the Gram-negative bacterial types showed resistance to these chemical ligands. Moreover, the antifungal test for the prepared ligand compounds exhibits no influence on the growth of the fungal strain C. albicans, except the ligand $\mathrm{SL}_{3}$ that showed very low activity with the zone of inhibition $9 \mathrm{~mm}$.

The metal complexes showed noteworthy enhancement antibacterial activity and were more toxic than the parent organic ligands against both the Gram-positive and the Gram-negative bacterial types. The metal complexes showed zones of inhibition in the range of 8-25 mm. The highest activity showed by the complex $\left[\mathrm{Co}\left(\mathrm{SL}_{3}\right)_{2}\right]$ against Gram-positive bacteria E. faecalis and S. epidermidis with the 
Table 2: Antibacterial and antifungal activity of the ligands and their Co(II), Fe(II), and Zn(II) complexes

\begin{tabular}{|c|c|c|c|c|c|c|c|}
\hline \multirow[t]{3}{*}{ Compound } & \multicolumn{7}{|c|}{ Zone of inhibition (mm) } \\
\hline & \multicolumn{3}{|c|}{ Gram-positive bacteria } & \multicolumn{3}{|c|}{ Gram-negative bacteria } & \multirow{2}{*}{$\begin{array}{l}\text { Fungus } \\
\begin{array}{l}\text { Candida } \\
\text { albicans }\end{array}\end{array}$} \\
\hline & $\begin{array}{l}\text { Staphylococcus } \\
\text { epidermidis }\end{array}$ & $\begin{array}{l}\text { Staphylococcus } \\
\text { aureus }\end{array}$ & $\begin{array}{l}\text { Enterococcus } \\
\text { faecalis }\end{array}$ & $\begin{array}{l}\text { Pseudomonas } \\
\text { aeruginosa }\end{array}$ & $\begin{array}{l}\text { Escherichia } \\
\text { coli }\end{array}$ & $\begin{array}{l}\text { Proteus } \\
\text { mirabilis }\end{array}$ & \\
\hline $\mathrm{SL}_{1}$ & 12 & 8 & 9 & 5 & $\mathrm{R}$ & $\mathrm{R}$ & $\mathrm{R}$ \\
\hline $\mathrm{SL}_{2}$ & 11 & 11 & 13 & 7 & $\mathrm{R}$ & $\mathrm{R}$ & $\mathrm{R}$ \\
\hline $\mathrm{SL}_{3}$ & 14 & 9 & 12 & 15 & $\mathrm{R}$ & 10 & 9 \\
\hline$\left[\mathrm{Ni}\left(\mathrm{SL}_{)_{2}}\right]_{3}\right.$ & 19 & 8 & 12 & $\mathrm{R}$ & $\mathrm{R}$ & 7 & $\mathrm{R}$ \\
\hline$\left[\mathrm{Fe}\left(\mathrm{SL}_{1}\right)_{2}\right]$ & 14 & 12 & 15 & $\mathrm{R}$ & $\mathrm{R}$ & 8 & $\mathrm{R}$ \\
\hline$\left[\mathrm{Co}\left(\mathrm{SL}_{1}\right)_{2}\right]$ & 8 & 16 & 13 & 8 & $\mathrm{R}$ & 23 & $\mathrm{R}$ \\
\hline$\left[\mathrm{Co}\left(\mathrm{SL}_{2}\right)_{2}\right]$ & 12 & 7 & 18 & $\mathrm{R}$ & $\mathrm{R}$ & 22 & $\mathrm{R}$ \\
\hline$\left[\mathrm{Ni}\left(\mathrm{SL}_{3}\right)_{2}\right]$ & 17 & 15 & 11 & 7 & $\mathrm{R}$ & 7 & $\mathrm{R}$ \\
\hline$\left[\mathrm{Fe}\left(\mathrm{SL}_{3}\right)_{2}\right]$ & 18 & 14 & 17 & $\mathrm{R}$ & $\mathrm{R}$ & 19 & 12 \\
\hline$\left[\mathrm{Co}\left(\mathrm{SL}_{3}\right)_{2}\right]$ & 24 & 16 & 25 & 15 & 10 & 23 & 13 \\
\hline Standard amoxicillin & 28 & 27 & 26 & 8 & 22 & 44 & - \\
\hline
\end{tabular}

Key to interpretation: $\mathrm{R}=0=$ Resistant, $<10 \mathrm{~mm}=$ inactive, $10-15 \mathrm{~mm}=$ weakly active, $15-20 \mathrm{~mm}=$ moderately active; more than $20 \mathrm{~mm}=$ highly active

zone of inhibition of $25 \mathrm{~mm}$ and $24 \mathrm{~mm}$, respectively. Furthermore, $\left[\mathrm{Co}\left(\mathrm{SL}_{3}\right)_{2}\right]$ complex exhibited good activity against the Gramnegative bacteria $P$. mirabilis with the zone of inhibition measured of $23 \mathrm{~mm}$. In addition, the compounds $\left[\mathrm{Co}\left(\mathrm{SL}_{1}\right)_{2}\right]$ and $\left[\mathrm{Co}\left(\mathrm{SL}_{2}\right)_{2}\right]$ showed high activity against the Gram-negative bacteria $P$. mirabilis with zones of inhibitions of 23 and $22 \mathrm{~mm}$, respectively. Moreover, on comparing with the reference antibacterial drug amoxicillin used for the treatment of bacterial infections, the compounds showed lower antibacterial activity.

The antifungal tests of the metal complexes indicated the resistance of the microorganisms to the metal complex chemicals, while some complexes $\left[\mathrm{Fe}\left(\mathrm{SL}_{3}\right)_{2}\right]$ and $\left[\mathrm{Co}\left(\mathrm{SL}_{3}\right)_{2}\right]$ showed weak antifungal activity (12 and $13 \mathrm{~mm}$ ) against C. albicans fungal strains, but a little higher than the parent organic ligands $\mathrm{SL}_{3}$ that showed inhibition zone of $9 \mathrm{~mm}$. However, the experimental observations (Table 2) indicated that the antifungal activity of the metal complexes was very weak compared to the antibacterial activity.

The remarkable enhancement in the antibacterial activity of the metal complexes compared to the organic Schiff base ligands might be referred to the impact of the transition metal ions in the metal complex compounds. The presence of metal ion in the complexes enhances the liposolubility of the compounds according to the Tweedy's chelation theory [49-51]. This enhancement in the lipophilicity of the metal complexes makes the penetration of the complexes into the lipid layers of the microbial cells and hence gives rise to adverse effects in the cell environment and enzymes of the cell and further restrict the proliferation of the microorganism [2,34]. In addition, the metal complexes hinder the respiration process of the cell and hence prevent the protein synthesis, which restrict further the organism growth.

Moreover, the mode of action of the compounds may involve the formation of a hydrogen bond through the azomethine nitrogen atom $(\mathrm{CH}=\mathrm{N})$ with the cell constituents causing in interference with the normal cell process [42].

The observations also reveal that metal complexes were more active against the Gram-positive bacterial strains E. faecalis and S. epidermidis than that of the Gram-negative ones and more than that of the fungal strain too. This variation in activity can be explained based on the difference in the cell wall structure difference between microorganisms and hence impermeability of the microorganism cells or in the differences in the ribosomes of the cell constituents $[29,42,50]$.

In general, the metal complexes deactivate different enzymes at the cellular level that has an essential role in different metabolic pathways of these microorganisms. Moreover, the solubility, conductivity, bond length between the metal and ligand, and dipole moment are important factors that affect the presence of the metal ions in the complexes that may enhance the antimicrobial activities of the coordination complex compounds compared the free organic Schiff base ligands [34].

The biological activity experimental results pointed out that the $\mathrm{Co}(\mathrm{II})$ metal complexes particularly $\left[\mathrm{Co}\left(\mathrm{SL}_{3}\right)_{2}\right]$ showed higher antibacterial activity compared with other analogous Fe(III) and Ni(II) complexes. Fe(III) and $\mathrm{Ni}(\mathrm{II})$ metal complexes generally have nearly similar activities with slight differences. The higher activity of $\mathrm{Co}(\mathrm{II})$ complexes may be attributed to their higher stability constant [52]. Since the complexes have different donating atoms and some other groups attached with the ligands, therefore the more effective factors that affect the antimicrobial activity are the nature of the central metal atom that plays a decisive role in determining the antimicrobial characteristics and the substituents and moieties that present in the ligands.

The observed antibacterial test results for the complex $\left[\mathrm{Co}\left(\mathrm{SL}_{3}\right)_{2}\right]$ which showed $25 \mathrm{~mm}$ zone of inhibition against $E$. faecalis bacteria encourage us to investigate the MIC to quantify the lowest concentration of the tested chemicals, which prevent visible growth of the selected bacteria. The MIC investigation indicated considerable high potency exhibited by the complex [Co(SL $\left.\mathrm{SL}_{3}\right)_{2}$ against $E$. faecalis bacterial strains with MIC value of $12.5 \mu \mathrm{g} /$ disc. The strong antibacterial activity of this particular metal complex may be due to the cobalt metal ion along with the Schiff base ligand that contains - SH group and heterocyclic quinoline ring. Fig. 8 shows some photographs for the antibacterial and fungal tests.

\section{In vivo molluscicidal assay}

Some of the obtained ligands and their corresponding metal complexes were tested for their molluscicidal activity against the land snail B. arabica. The toxicity and $\mathrm{LD}_{50}$ were determined for the tested compounds according to the WHO guidelines using the immersion technique and using niclosamide as a positive control [27]. The number of mortalities and $50 \%$ death $\left(\mathrm{LD}_{50}\right)$ values are shown in Table 3.

For this molluscicidal activity investigation, we have selected two ligands $\mathrm{SL}_{2}$ and $\mathrm{SL}_{3}$ and the corresponding metal complexes $\left[\mathrm{Fe}\left(\mathrm{SL}_{2}\right)_{2}\right],\left[\mathrm{Co}\left(\mathrm{SL}_{2}\right)_{2}\right],\left[\mathrm{Ni}\left(\mathrm{SL}_{2}\right)_{2}\right],\left[\mathrm{Co}\left(\mathrm{SL}_{3}\right)_{2}\right],\left[\mathrm{Ni}\left(\mathrm{SL}_{3}\right)_{2}\right]$, and $\left[\mathrm{Fe}\left(\mathrm{SL}_{3}\right)_{2}\right]$. The observation is presented in Table 3 indicated that the ligands showed activity at the concentration of $1000 \mathrm{ppm}$ while their metal complexes show activity at concentrations of $500 \mathrm{ppm}$. The complexes showed good activity at a concentration of $1000 \mathrm{ppm}$ and the highest activity was at a concentration of $5000 \mathrm{ppm}$. It is also noted that the 

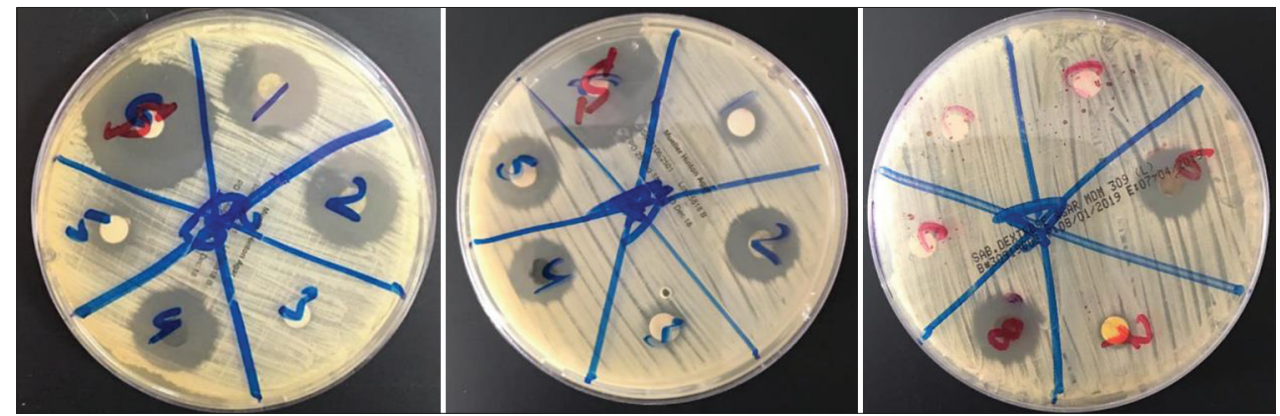

Fig. 8: Some photographs for the antibacterial and fungal tests
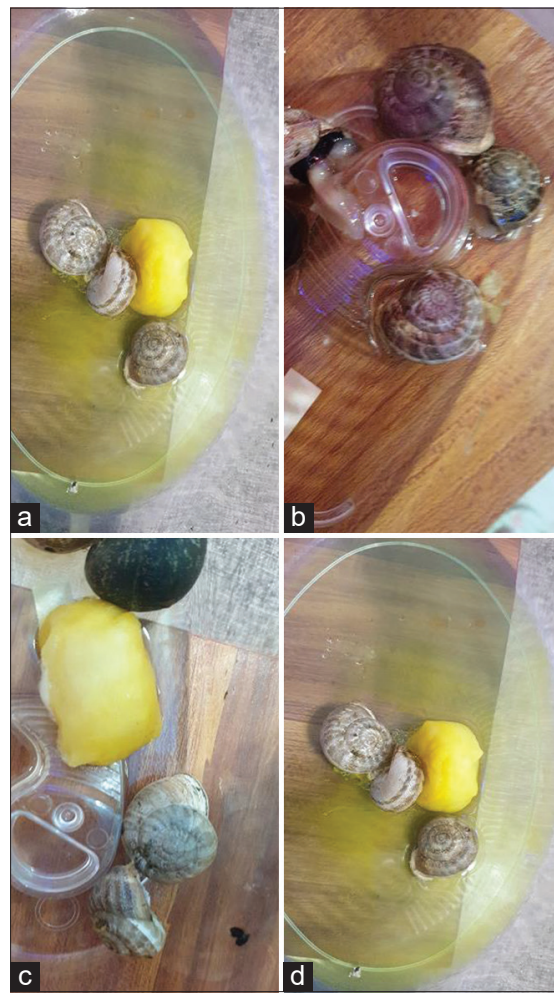

Fig. 9: (a-d) Photograph of molluscicidal activity tests

Table 3: Molluscicidal activity of the selected compounds against Biomphalaria arabica snails

\begin{tabular}{lllll}
\hline \multirow{2}{*}{ Compounds } & \multicolumn{2}{l}{ Number of mortalities } & \\
\cline { 2 - 5 } & $\mathbf{1 0 0} \mathbf{~ p p m}$ & $\mathbf{5 0 0} \mathbf{~ p p m}$ & $\mathbf{1 0 0 0} \mathbf{~ p p m}$ & $\mathbf{5 0 0 0} \mathbf{~ p m}$ \\
\hline $\mathrm{SL}_{2}$ & - & - & 1 & 2 \\
$\mathrm{SL}_{3}$ & - & 1 & 2 & 4 \\
{$\left[\mathrm{Co}\left(\mathrm{SL}_{2}\right)_{2}\right]$} & - & - & - & 4 \\
{$\left[\mathrm{Ni}\left(\mathrm{SL}_{2}\right)_{2}\right]$} & - & - & 2 & 4 \\
{$\left[\mathrm{Fe}\left(\mathrm{SL}_{2}\right)_{2}\right]$} & - & 2 & 4 & 5 \\
{$\left[\mathrm{Co}\left(\mathrm{SL}_{3}\right)_{2}\right]$} & - & 3 & 4 & 5 \\
{$\left[\mathrm{Ni}\left(\mathrm{SL}_{3}\right)_{2}\right]$} & - & - & 4 & 4 \\
{$\left[\mathrm{Fe}\left(\mathrm{SL}_{3}\right)_{2}\right]$} & - & - & 3 & 5 \\
\hline
\end{tabular}

complexes are more active than their parent ligands, which may be explained because of the presence of metal ion that may enhance the molluscicidal activity. The $\mathrm{LD}_{50}$ of the complexes was higher at a concentration of $1000 \mathrm{ppm}$ and $5000 \mathrm{ppm}$ compared to the free organic ligands. Fig. 9 shows some photographs of molluscicidal activity tests.

\section{CONCLUSION}

In the present research work, we prepared unsymmetrical tridentate Schiff base ligands using 2-aminotheiophenol condensed with three aldehydes named 2-carboxybenzaldehyde, 2-hydroxy-1naphthaldehyde, and 7-formy-8-hydroxyquinoline. The unsymmetrical Schiff base ligands were utilized in the preparation of metal complexes with the iron triad transition metal ions (Fe(II), Co(II), and Ni(II)). The prepared compounds were characterized and their structures were proposed and confirmed using different physical and spectroscopic techniques. The analysis data suggested an octahedral geometry around the metal ions. The molar conductivity study showed that metal complexes were non-electrolytic in nature.

The antimicrobial observation data showed that the metal complexes were more biologically active compared to their parent organic Schiff base ligands. The complexes with cobalt metal ion showed the highest activity against the Gram-positive bacterial strains. The free ligands showed no activity against $C$. albicans fungal strains and their corresponding metal complexes showed weak activity.

The in vivo molluscicidal activity evaluation tests showed that ligands and their corresponding metal complexes were having good molluscicidal activity against the tested snails. The metal complexes were more active than the parent-free ligands.

\section{ACKNOWLEDGMENTS}

The authors would like to thank the Chairman of the Chemistry Department for Laboratory Facilities and the Dean, Faculty of Science, Al-Baha University for encouragement.

\section{AUTHORS' CONTRIBUTIONS}

All authors contributed to the design, experimentation, and interpretation of results. Manuscript preparation and edition were done by corresponding author Dr. Sami A. Zabin and approved by the coauthors Amal M. Alosaimi and Dr. Ines El Mannoubi.

\section{CONFLICTS OF INTEREST}

The authors declare that they have no potential conflicts of interest.

\section{AUTHORS FUNDING}

The authors received no specific funding for this work.

\section{REFERENCES}

1. Dehghani-Firozabadi AA, Sobhani M, Notash B. Synthesis and characterization of metal complexes with NOS unsymmetrical tridentate Schiff base ligand. X-ray crystal structures determination of nickel(II) and copper(II) complexes. Polyhedron 2016;119:49-54.

2. Zabin $\mathrm{SA} . \mathrm{Cu}(\mathrm{II})$ and $\mathrm{Ni}$ (II) complexes derived from tridentate ligands with $\mathrm{N}=\mathrm{N}$ and $\mathrm{CH}=\mathrm{N}$ linkages: Characterization and antimicrobial activity. Albaha Univ J Basic Appl Sci 2017;1:9-18. 
3. Imer AG, Syan RH, Gulcan M, Ocak YS, Tomback A. The novel pyridine based symmetrical Schiff base ligand and its transition metal complexes: Synthesis, spectral definitions and application in dyesensitized solar cells (DSSCs). J Mater Sci 2018;29:898-905.

4. Al-Obiadi OH. Synthesis, characterization and theoretical treatment of sandwich Schiff bases complexes derived from salicylaldehyde with some transition metals and study of its biological activity. Int J Chem Res 2012;3:1-5.

5. Vairalakshmi M, Princess R. Metal complexes of novel Schiff base containing isatin: Characterization, antimicrobial, antioxidant and catalytic activity study. Asian J Pharm Clin Res 2019;12:206-10.

6. de Fátima Â, Pereira CP, Olímpio CR, de Freitas Oliveira BG, Franco LL, da Silva PH. Schiff bases and their metal complexes as urease inhibitors a brief review. J Adv Res 2018;13:113-26.

7. Abdel-Rahman LH, Abu-Dief AM, Adan MS, Hamdan SK. Some new nano-sized mononuclear $\mathrm{Cu}(\mathrm{II})$ Schiff base complexes: Design, characterization, molecular modeling and catalytic potentials in benzyl alcohol oxidation. Catal Lett 2016;46:1373-96.

8. Bastos AM, da Silva JG, Maia PI, Deflon VM, Batista AA, Ferreira AV, et al. Oxovanadium(IV) and (V) complexes of acetylpyridinederived semicarbazones exhibit insulin-like activity. Polyhedron 2008;27:1787-94.

9. Grivani G, Bruno G, Rudbari HA, Khalaji AD, Pourteimouri P. Synthesis, characterization and crystal structure determination of a new oxovanadium (IV) Schiff base complex: The catalytic activity in the epoxidation of cyclooctene. Inorg Chem Commun 2012;8:15-20.

10. Ejidike IP, Ajibade PA. Synthesis, characterization, anticancer, and antioxidant studies of $\mathrm{Ru}$ (III) complexes of monobasic tridentate Schiff bases. Bioinorg Chem Appl 2016;2016:11.

11. Sarkar S, Boceli G, Cantoni A, Ghosh A. Copper (II) complexes of symmetrical and unsymmetrical tetradentate Schiff base ligands incorporating 1-benzoylacetone: Synthesis, crystal structures and electrochemical behavior. Polyhedron 2008;27:693-700

12. Kolawole GA, Osowole AA. Synthesis and characterization of some metal(II) complexes of isomeric unsymmetrical Schiff bases and their adducts with triphenylphosphine. J Coord Chem 2009;62:1437-48.

13. Khalaji AD, Ghorbani M, Feizi N, Akbari A, Eigner V, Dusek M. A novel trinuclear copper (II) complex containing a symmetric tetradentate $\mathrm{N}_{2} \mathrm{O}$, Schiff base ligand: Synthesis, characterization, crystal structure and its usage as a new precursor for the preparation of $\mathrm{CuO}$ particles. Polyhedron 2017;121:9-12

14. Alzahrani AA, Zabin SA, Jammali $\mathrm{M}$. The bivalent $\mathrm{Cu}, \mathrm{Ni}$ and $\mathrm{Zn}$ complexes of unsymmetrical ONO tridentate Schiff base ligands derived from 2-aminobenzoic acid: Antimicrobial and molluscicidal activity. J Org Inorg Chem 2018;4:1-16.

15. Ejidike IP, Ajibade PA. Transition metal complexes of symmetrical and asymmetrical Schiff bases as antibacterial, antifungal, antioxidant, and anticancer agents: Progress and prospects. Rev Inorg Chem 2015;35:191-224.

16. Liu X, Manzur C, Novoa N, Celedón S, David CD, Hamon JR. Review: Multidentate unsymmetrically-substituted Schiff bases and their metal complexes: Synthesis, functional materials properties, and applications to catalysis. Coord Chem Rev 2018;357:144-72.

17. Gradinaru J, Forni A, Druta V, Tessore F, Zecchin S, Quici S, et al. Structural, spectral, electric-field-induced second harmonic, and theoretical study of $\mathrm{Ni}(\mathrm{II}), \mathrm{Cu}(\mathrm{II}), \mathrm{Zn}(\mathrm{II})$, and $\mathrm{VO}(\mathrm{II})$ complexes with $\left[\mathrm{N}_{2} \mathrm{O}_{2}\right]$ unsymmetrical Schiff bases of S-methyl isothiosemicarbazide derivatives. Inorg Chem 2007;46:884-95.

18. Al-Jebouri GS, Noorikhaleel AM. Synthesis of new boron compounds with amoxiciline and some of its metal complexes with use them in antibacterial, assessment of hepatoprotictive and kidneyactivity, anticancer and antioxidant applications. Asian J Pharm Clin Res 2019;12:1-9

19. Shafaatian B, Ozbakzaei Z, Notash B, Rezvani SA. Synthesis, characterization, single crystal X-ray determination, fluorescence and electrochemical studies of new dinuclear nickel(II) and oxovanadium(IV) complexes containing double Schiff base ligands. Spectrochim Acta A Mol Biomol Spectrosc 2015;140:248-55.

20. Kalita M, Bhattacharjee T, Gogoi P, Barman P, Kalita RD, Sarma B, et al. Synthesis, characterization, crystal structure and bioactivities of a new potential tridentate (ONS) Schiff base ligand $N$-[2-(benzylthio) phenyl] salicylaldimine and its $\mathrm{Ni}(\mathrm{II}), \mathrm{Cu}(\mathrm{II})$ and $\mathrm{Co}(\mathrm{II})$ complexes. Polyhedron 2013;60:47-53

21. Patel VK, Vasanwala AM, Jejurkar CR. Synthesis of mixed Schiff base complexes of $\mathrm{Cu}(\mathrm{II})$ and $\mathrm{Ni}(\mathrm{II})$ and their spectral, magnetic and antifungal studies. Indian J Chem 1989;28A:719-21.

22. Ismail T. Mononuclear and binuclear $\mathrm{Co}(\mathrm{II}), \mathrm{Ni}(\mathrm{II}), \mathrm{Cu}(\mathrm{II}), \mathrm{Zn}(\mathrm{II})$ and $\mathrm{Cd}(\mathrm{II})$ complexes of Schiff-base ligands derived from 7-formyl8-hydroxyquinoline and diaminonaphthalenes. J Coord Chem 2004;58:141-51.

23. Uddin MN, Chowdhury DA, Islam MT, Hoque F. Evaluation of biological activity of dioxouranium complexes of some Schiff base and dithiocarbamate ligands. Orbital Electron J Chem 2012;4:273-87.

24. Shafaatian B, Mousavi SS, Afshari S. Synthesis, characterization, spectroscopic and theoretical studies of new zinc(II), copper(II) and nickel(II) complexes based on imine ligand containing 2-aminothiophenol moiety. J Mol Struct 2016;1123:191-8.

25. Abdelbaset M, Zabin SA, Alorabi AQ. Synthesis and in vitro biological examination of dioxovanadium (v) mixed- ligand complexes containing 4-amino-5-mercapto-3-phenyl-1,2,4-triazole as primary Ligand and o-aniline derivatives as co-ligands. Int J Biol Pharm Allied Sci 2019;8:672-44.

26. Alzahrani AA, Jammali M, El Mannoubi I, Zabin SA. Molluscicidal and antimicrobial activity of binary mononuclear metal complexes of bidentate azomethine ligands based on anthranilic acid. Int J Biol Pharm Allied Sci 2019;8:319-41.

27. He P, Wang W, Sanogo B, Zeng X, Sun X, Lv Z, et al. Molluscicidal activity and mechanism of toxicity of a novel salicylanilide ester derivative against Biomphalaria species. Parasit Vectors 2017;10:383.

28. El-Sherbini GT, Zayed RA, El-Sherbini ET. Molluscicidal activity of some Solanum species extracts against the snail Biomphalaria alexandrina. J Parasitol Res 2009;2009:5.

29. Salehi M, Rahimifar F, Kubicki M, Asadi A. Structural, spectroscopic, electrochemical and antibacterial studies of some new nickel(II) Schiff base complexes. Inorganica Chim Acta 2016;443:28-35

30. More G, Raut D, Aruna K, Bootwala S. Synthesis, spectroscopic characterization and antimicrobial activity evaluation of new tridentate Schiff bases and their Co(II) complexes. J Saudi Chem Soc 2017;21:954-64.

31. Ozkan G, Kose M, Zengin H, McKee V, Kurtoglu M. A new salentype azo-azomethine ligand and its $\mathrm{Ni}(\mathrm{II}), \mathrm{Cu}(\mathrm{II})$ and $\mathrm{Zn}(\mathrm{II})$ complexes: Synthesis, spectral characterization, crystal structure and photoluminescence studies. Spectrochim Acta A Mol Biomol Spectrosc 2015;150:966-73.

32. Esmadi FT, Khabour OF, Abbas K, Mohammad A, Obeidat RT, Mfady D. Synthesis, characterization and biological activity of some unsymmetrical Schiff base transition metal complexes. Drug Chem Toxicol 2016;39:41-7.

33. Panchal PK, Pansuriya B, Patel MN. In vitro biological evaluation of some ONS and NS donor Schiff bases and their metal complexes. J Enzyme Inhib Med Chem 2006;21:453-8.

34. Alias M, Kassum H, Shakir C. Synthesis, physical characterization and biological evaluation of Schiff base M(II) complexes. J Assoc Arab Univ Basic Appl Sci 2014;15:28-34.

35. Mahmoud WH, Deghadi RG, Mohamed GG. Spectroscopic and thermal characterization of biologically and anticancer active novel Schiff base metal complexes. Res Chem Intermed 2016;42:7869-907.

36. Al-Najjar N. Preparation and identification of some PVA metal complexes. Iraqi J Sci 2009;50:271-8.

37. Nartop D, Gürkan P, Sari N, Çete S. Tetradentate asymmetric Schiff bases and their Ni(II) and Fe(III) complexes. J Coord Chem 2008;61:3516-24.

38. Asadi M, Hemmateenejad B, Mohammadikish M. Synthesis, characterization, and formation constant of hexa-coordinate iron(III) complexes. J Coord Chem 2010;63:124-35.

39. Jayaseelan P, Prasad S, Vedanayaki S, Rajavel R. Synthesis, characterization, anti-microbial, DNA binding and cleavage studies of Schiff base metal complexes. Arabian J Chem 2016;9:S668-77.

40. Wang Y, Yang Z, Wang B. Synthesis, Characterization and antioxidative activity of cobalt(II), nickel(II) and iron(II) Schiff base complexes. Trans Met Chem 2005;30:879-83.

41. Alghool S, Abd El-Halim HF, Dahshan A. Synthesis, spectroscopic thermal and biological activity studies on azo-containing Schiff base dye and its cobalt(II), chromium(III) and strontium(II) complexes. J Mol Struct 2010;983:32-8.

42. Alaghaz AM, Ammar YA, Bayoumi HA, Aldhlmani SA. Synthesis, spectral characterization, thermal analysis, molecular modeling and antimicrobial activity of new potentially $\mathrm{N}_{2} \mathrm{O}_{2}$ azo-dye Schiff base complexes. J Mol Struct 2014;1074:359-75

43. Zayed EM, Mohamed GG, Hassan WM, Elkholy AK. Spectroscopic, thermal, biological activity, molecular docking and density functional theoretical investigation of novel bis Schiff base complexes. Appl Organomet Chem 2018;32:e4375.

44. Abou-Hussain AA. Spectroscopic and biological studies of mono or 
binuclear complexes derived from thio-Schiff bases of some transition metals. J Sulfur Chem 2010;31:427-46.

45. Patel RN, Singh A, Shukla KK Patel DK, Sondhiya VP, Dwivedi S. Synthesis, spectral and structural study of sulfur-containing copper(II) complexes. J Sulfur Chem 2010;31:299-313.

46. Tajudeen SS, Kannappan G. Schiff Base copper(II) complexes: Synthesis, spectral studies and anti-tubercular and antimicrobial activity. Indian J Adv Chem Sci 2016;4:40-8.

47. El-Asmy AA, El-Sonbati AZ, Ba-Issa AA. Synthesis and properties of 7-formyl-8-hydroxyquinoline and its transition metal complexes. Trans Met Chem 1990;15:222-5.

48. Abdel Aziz AA, El-Sayed IS, Khalil MM. Some divalent metal(II) complexes of novel potentially tetradentate Schiff base N,N-bis(2carboxyphenylimine)-2,5-thiophenedicarboxaldehyde: Synthesis, spectroscopic, characterization and bioactivities. Appl Organomet
Chem 2017;31:e3730

49. Gupta R, Agrawal N, Gupta KC. Synthesis, IR spectral studies and biological activities of some rare earth metal complexes with biochemically relevant ligand. Res J Pharm Biol Chem Sci 2012;3:50-6.

50. Al-Amiery A, Kadhum AAH, Mohamad A. Antifungal and antioxidant activities of pyrrolidone thiosemicarbazone complexes. Bioinor Chem Appl 2012;2012:6.

51. Zabin SA, Abdelbaset M. Oxo/dioxo-vanadium (V) complexes with Schiff base ligands derived from 4-amino-5-mercapto-3-phenyl-1, 2, 4-triazole. Eur J Chem 2016;7:322-8.

52. El-Sherif AA, Shoukry MM, Abd-Elgawad MM. Synthesis, characterization, biological activity and equilibrium studies of metal(II) ion complexes with tridentate hydrazone ligand derived from hydralazine. Spectrochimica Acta A Mol Biomol Spectrosc 2012;98:307-21 